\title{
Microbiological Evaluation of Surgical Site Infections in the Clinic of Oral and Maxillofacial Surgery of the Sf.Spiridon Clinical Hospital in lasi, Romania
}

\author{
MAGDA CALINA BARLEAN ${ }^{1}$, CARINA BALCOS2*, LIVIA IONELA BOBU ${ }^{3 *}$, COSMIN IONUT CRETU4, ALEXANDRA LORINA PLATON ${ }^{5}$, \\ ANCA STUPU6 ${ }^{6}$, OVIDIU NICOLAICIUC ${ }^{7}$, GABI TOPOR ${ }^{9}$, ADRIAN BEZNEA ${ }^{9}$, EUGENIA POPESCU ${ }^{8}$ \\ ${ }^{1}$ Grigore T.Popa University of Medicine and Pharmacy lasi, Romania, Faculty of Dental Medicine, 16 Universitatii Str. 700115 \\ ${ }^{9}$ Dunarea de J os University of Galati, Faculty of Medicine and Pharmacy, 47 Domneasca Str., 800008, Galati, Romania
}

\begin{abstract}
The study aims to evaluatethe bacteriological profile of the surgical site infections at the Clinic of Oral and Maxillofacial Surgery of the Sf.Spiridon Clinical Hospital in lasi, Romania between 2011 and 2018. Microbiological data were obtained from the Microbiology Laboratory of the Sf.Spiridon Emergency Clinical Hospital lasi. 125 surgical site infections, accounting for $54,1 \%$ of health care associated infections were reported in 106 patients, representing 66,6\% of the patients with HAl. The most commonly identified pathogens were Klebsiella Pneumoniae, Staphylococcus aureus, Acinetobacter baumanii and Pseudomonas aeruginosa.A high level of antibiotic resistance was reported. Prevention of SSI and antibiotic resistance control are complex and require coordinated measures in view of an integrated, multidisciplinary approach.
\end{abstract}

Keywords: surgical site infection, antibiotic resistance, prevention

Healthcare associated infections (HAl) are infections occurring during health care and they are a major problem in healthcare systems worldwide [1]. The term of healthcare associated infection initially referred to those hospital-related infections (previously called nosocomial infections), includes today the infections developed in various locations where patients receive healthcare (hospitals, ambulatory medical institutions, long-term health care institutions, family medicine clinics, home care) [2].

HAl affect a large number of patients worldwide, significantly increasing the mortality rate and the financial losses associated with medical care.In Europe The Centre for Disease Control and Prevention (ECDC) appreciates that of the 100 hospitalized patients, 7 patients in advanced countries and 10 in developing country acquire an HAl. Following the conclusions of extended reviews in the literature a report drawn up in 2016 by the World Health Organization pointed outthat the prevalence of $\mathrm{HAl}$ varies according to the socio-economic status with estimated values between $3.5 \%$ and $12 \%$ in the countries with high socio-economic status, compared to $5.7 \%$ - $19.1 \%$ (average prevalence $10.1 \%$ ) in the middle and low income countries $[3,4]$.

The most common locations of $\mathrm{HAl}$ are the surgical site, the urinary tract and lungs, but theycan affect the digestive system or can cause serious systemic infections. $[5,6]$ The CDC in partnership with the World Health Organization and other organizations and agencies around the world are making sustained efforts that are reflected in the adopted specific strategies involving actions at institutional, national and international level. In Romania, these regulations at national level are included in Order no. $1101 / 2016$ on the approval of the Norms for the surveillance, prevention and limitation of healthcare associated infections in medical establishments [7].

Surgical site infections (SSI) are the most common type of HAlmainly in low and middle income countries with an incidence between 1.2 and 23.6 per 100 surgical procedures and an average of $11.8 \%$ compared to the incidence reported in developed countries ranging between $1.2 \%$ and $5.2 \%$ [ 8 ]. SSI are defined as infections occurring up to 30 days after surgery and affecting the incision or tissues at the site of the surgical intervention. Despite advances in prevention, SSI remains a major clinical problem because they are associated with significant mortality and morbidity and require considerable medical resource demand.

Thesurgery interventions for head and neck cancerare frequently associated with SSI which are reported to be the most common and significant complications despite antibiotic prophylaxis $[9,10]$. These infections can causeserious complications, asimportant deterioration of the operative wound, mucocutaneous fistula, sepsis and death $[11,12]$.

Microbiological evaluations highlighted that the first identified pathogens involved in HAl were the Grampositive species, particularly Streptococci and Staphylococcus aureus, which caused major nosocomial infections culminating with the 1940-1950's pandemic. At the end of the 20th century Gram-positive bacteria (Staphylococcus aureus, Coagulase-negative Staphylococci and Enterococci) and Gram-negative bacteria (Escherichia coli, P. aeruginosa, Enterobacter spp. and Klebsiella pneumoniae) accounted for $34 \%$ and respectively $32 \%$ of pathogens associated with HAI [13].

Acquired antimicrobial resistance is the main problem in hospital units involving major Gram-positive and Gramnegative pathogens $[14,15]$. In 2013, CDC published a report on the main 18 antibiotic-resistant pathogens frequently associated with the aetiology of HAl, classified by risk. At present, the pathogens under surveillance for antibiotic resistance are Streptococcus pneumoniae, Staphylococcus aureus, Enterococcus faecalis, Enterococcus faecium, Escherichia coli, Klebsiella pneumoniae, Pseudomonas aeruginosa, and Acinetobacter spp. [16,17].

*email: carinutza 2005@yahoo.com; livia12mi@yahoo.com 
The World Health Organization classifies pathogens according to the evolution of their antibiotic resistance in three priority levels: Critical,High and Average highlighting the need for vigorous measures to control this phenomenon [18]. In the critical category are included Acinetobacter baumanniicarbapenem - resistant Pseudomonas aeruginosa 3 rd generation cephalosporin-resistant Pseudomonas aeruginosa, 3 rd generation cephalosporinresistant. Surprisingly, Clostridium difficile is not included in the WHO list, although the incidence and severity of infections caused by this pathogen have increased dramatically since the beginning of the 2000s across Europe [19].

\section{Experimental part}

Materials and methods

A retrospective study was carried out at the Clinic of Oral and Maxillofacial Surgery of the Sf.Spiridon Clinical Hospital Iasi, Romania, regarding the microbiology of the surgical site infections reported between 2011-2018. The database of the Medical Care Associated Infections Surveillance and Prevention Department( statistical reports, epidemiological surveys, results of the medical investigations) for the period 2011-2018 was accessed with the consent of the management of the Sf.Spiridon Emergency Clinical Hospital Sf.Spiridon lasi . HAI detection was performed by active epidemiological surveillance. HAl cases were analysed in correlation with the data included in the General Clinical Observation Sheet of the patients in the Archives of the Oral and Maxillofacial Surgery Clinic of the Sf.Spiridon Emergency Clinical Hospital in lasi.

Microbiological evaluation regarding the identification of the involved pathogens and their susceptibility to antibiotics were performed at the Microbiology Laboratory of the Sf.Spiridon Clinical Hospital lasi.

Statistical analysis of the data was performed using theSPSS 20 system (SPSS Inc., Chicago, IL, USA). Chisquare and Fisher tests were used to compare the variables. The statistical significance was set at $p<0.05$.

\section{Results and discussions}

A total number of 231 healthcare associated infections (HAl) were reported in Oral and Maxillofacial Surgery Clinic at the Sf.Spiridon Clinical Hospital in lasi between 20112018, involving 154 patients. Thisinvestigation results are consistent with those reported by the World Health Organization on the prevalence of HAl as being between $5.7 \%$ and $19.1 \%$ (mean value $10.1 \%$ ) for middle and low income countries [3]. They show to be higher than the average of $6 \%$ patients with at least one HAl reported by the European Centre for Disease Control and Prevention (ECDC) for 231,459 patients in 947 hospitals in 30 European countries. [20] HAl are caused by antibioticenhanced pathogens, hospitalized patients undergoing surgery frequently experiencing comorbidities associated with compromised immune systems that do not provide the necessary level of protection. In some cases, patients develop HAl infections due to non-compliance with hygiene conditions and infection prevention protocols in healthcare facilities due to under-funding or lack of knowledge and responsibility of healthcare professionals [21].
125 surgical site infections (SSI) have been reported accounting for $54.1 \%$ of the total HAl diagnosed in 106 patients, representing $66,6 \%$ of all patients with HAl. Those results are well above the value of $33 \%$ reported at the European level [20] and by other authors: 10.0\%-Ogihara [22], 28.3\% - Yang [23]. The SSI incidence in the literature is appreciated to be up to $20 \%$, depending on the surgical procedure, the used surveillance criteria, and the quality of the data collection [6]. SSI have important consequences on the progression and prognosis of the patient's initial hospitalization disease, but also on the financial burden in relation with the increased number of hospitalization days and the required specific treatment [24].

29 SSI (23.2\%) were diagnosed in female patients and $96(76.8 \%)$ in male patients. The patients 'gender was a significant risk factor for SSI in the current study, $76.9 \%$ of the patients with reported SSI being men. This finding is consistent with the studies of Park in 2016 [5], BelusicGobic et al. in 2007 [26] and Lee et al. in 2011 [9], while other studies have reported significant association between those infections and other factors as basic systemic diseases (Schwart et al., 2004) [27].

Depending on the location SSI are classified as superficial involving only cutaneous and subcutaneous tissues and deep affecting the deep soft tissue of the incision. They imply signs as purulent drainageor a nonhistological abscess, spontaneous dehiscence of the wound with symptoms of infection (swelling, erythema, warmth and tenderness) and isolation of a pathogen in the purulent discharge $[28,29]$. In our study 57 SSI, representing $46,6 \%$ of total number of SSI and $24.6 \%$ of the total HAl, were superficial and 68 ( $54.4 \%$ of the SSI and $29.4 \%$ of HAI were deep. The distribution of SSI cases per year between 2011 and 2018 is shown in Table 1.

Most SSI (80\%) were associated with surgical procedures in patients diagnosed with head and neck cancer who required interventions on wide and deep tissue and / or flap reconstruction approaches.. In its study on SSI in 697 patients with major head and neck cancer surgery, Lee etal., 2011 [9] mentions the associated radiotherapy, the tracheotomy and the exposure to contamination as risk factors for those infectious complications. The occurrence of postoperative complications was also associated with disease severity, type of surgery and type of reconstruction [30]. Complications following major surgery for oral cancer patients increase the cost of treatment, delay adjuvant therapies, increase the risk of sequelae, affect the patient quality of life, and also may cause the death of a patient if they are not properly diagnosed and treated [22,31].

The average period of hospitalization for the patients diagnosed with SSI was 30 days, much higher than the average of 5-7 days (between 2.5 and 7.8 days) reported in Europe [15]. The emergence of an SSI may lead to a prolongation of hospitalization period, increased health care costs and delayed access to postoperative therapy [33].

Microbiological data ( pathogens identification and their susceptibility to antibiotics) was obtained in all 106 patients with SSI. For 82 of them $(65.6 \%$ of SSI), one pathogen agent was identified while $43(34.4 \%)$ were associated with two or more pathogens.

\begin{tabular}{|c|c|c|c|c|c|c|c|c|c|}
\hline \multirow[t]{2}{*}{ SSI } & \multicolumn{9}{|l|}{ Year } \\
\hline & 2011 & 2012 & 2013 & 2014 & 2015 & 2016 & 2017 & 2018 & TOTAL \\
\hline Superficial & 7 & 4 & 7 & 7 & 8 & 1 & 16 & 7 & 57 \\
\hline Deep & 2 & 8 & 8 & 5 & 13 & 20 & 8 & 4 & 68 \\
\hline TOTAL & 9 & 12 & 15 & 12 & 21 & 21 & 24 & 11 & 125 \\
\hline
\end{tabular}

Table 1

YEARLY DISTRIBUTION OF SURGICAL SITE INFECTIONS ( 2011-2018) 
The assessment of the main determinants of $\mathrm{HAl}$ is an essential step in identifying the strategies and efficient measures for their control [32]. In hospital units the sources of infection are represented by patients, healthcare professionals and environment, but there are situations in which they remain unidentified. The oral cavity is a natural habitat for over 500 opportunistic and pathogenic microbial species, an ecological niche that increases the risk of infection transmission locally, regionally and systemically by exposure to microorganisms during invasive procedures of oral surgery.

The most commonly identified pathogens from the 174 isolates for SSI were Klebsiella Pneumoniae -18.4\%, Staphylococcus aureus $18.4 \%$, Acinetobacter baumanii $17.2 \%$ and Pseudomonas aeruginosa $-14.4 \%$, followed by Escherichia coli - 5.7\%, Enterococcus faecalis - 5.2\%, Enterobacter spp. 4\% and Staphylococcus epidermidis 2.9\%. (fig.1)

An impressive number of studies in the literature aim to identify the most involved in SSI pathogens.Our study data are comparable with the results of extensive studies conducted in France, Germany and Italy, including 13954 isolates in which the most common reported pathogens were Staphylococcus aureus (21.8\%), Enterobacteriaceae (20.2\%), Pseudomonas spp. (17.2\%), Enterococci (10.0\%), Escherichia coli (9.1\%), Candida spp (8.8\%), Coagulasenegative staphylococci (7.0\%) and Acinetobacter spp (5.1\%). [3] An increased frequency of Klebsiella pneumoniae isolations must be mentioned as a result of the present investigation. Of the total of 167 strains of isolated bacteria involved in the aetiology of SSI , 113 (67.7\%) were Gram-negative bacteria and 54 (32.3\%) Gram-positive bacteria, results comparable with those highlighted by a recently published synthesis study based on 28 studies in developing countries which reported that
Gram-negative bacteria are the pathogens most commonly associated with HAl in all patients as well as in patients at high risk.(fig.2)[9]. For emerging countries, a growing proportion of nosocomial infections attributed to Gramnegative bacteria and to methicillin-resistant Staphylococcus aureus(MRSA) have been reported by Fehr et al. 2006 [34], Rosenthal et al. 2006 [35] and Kadkhodaei, 2018 [36].

The assessment of antibiotic susceptibilitywas performed for the main pathogens involved in the aetiology of SSI. In order to categorise the resultsEuropean Committee for Antimicrobial Susceptibility Testing (EUCAST) breakpoints are used as S- Susceptible, standard dosing regimen, I - Susceptible, increased exposure by adjusting the dosing regimen or by its concentration at the site of infection and R - Resistant.[26,37]

Klebsiella pneumoniae strains were susceptible over $80 \%$ to Ertapenem (ETP) (87.5\%), Meropenem (MER) (82.6\%), Colistin (COL) (82.4\%), Imipenem (IMI) (81.0\%) and Amikacin AMK (AK) (81.0\%). Antibiotic resistance was reported toGentamicin (GM) (73.7\%) Amoxicillinclavulanic acid (AMC) (72.4\%), Tobramycin (TOB) (68.9\%), Ceftazidime (CAZ) Ceftriaxone (CTX) (61.9\%) (61.5\%) (fig. 3) At European level, more than one-third (34.5\%) of $K$. pneumoniae isolates reported at EARS-Net in 2016 were resistant to at least one of the periodically supervised antimicrobial groups (fluoroquinolones, third generation cephalosporins, aminoglycosides and carbapenems) For Romania , a resistance of more than $50 \%$ was found for fluoroquinolones, third generation cephalosporins, aminoglycosides, carbapenems and combined resistance (fluoroquinolones, third generation cephalosporins and aminoglycosides) and between $25 \%$ and $50 \%$ for carbapenems [17].

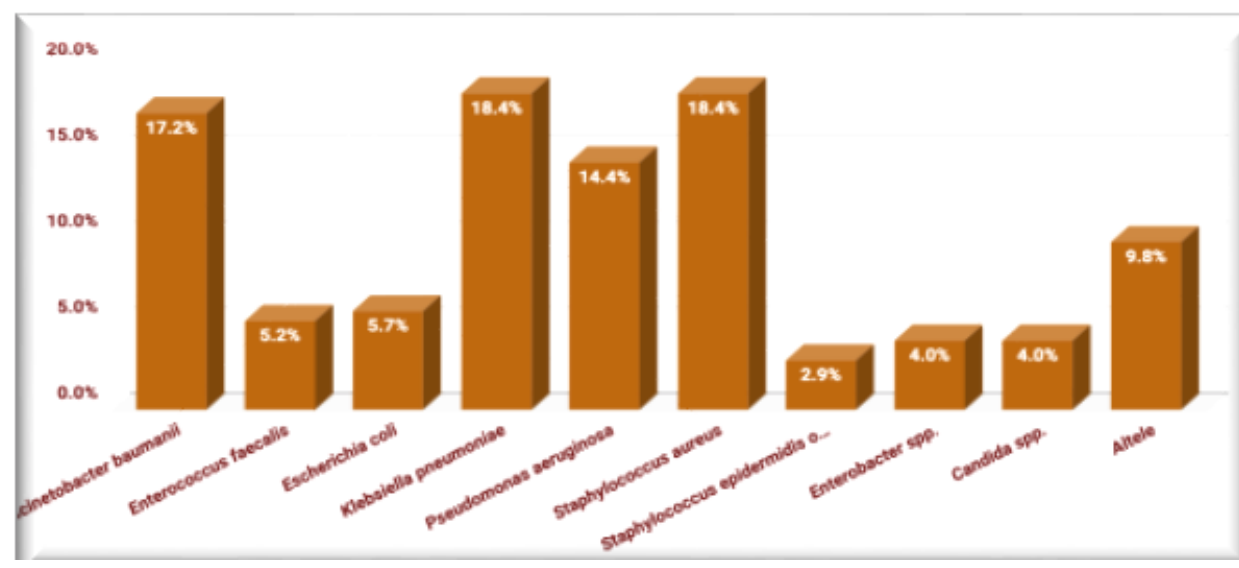

Fig. 1.Patogenic bacteria isolated from SSI

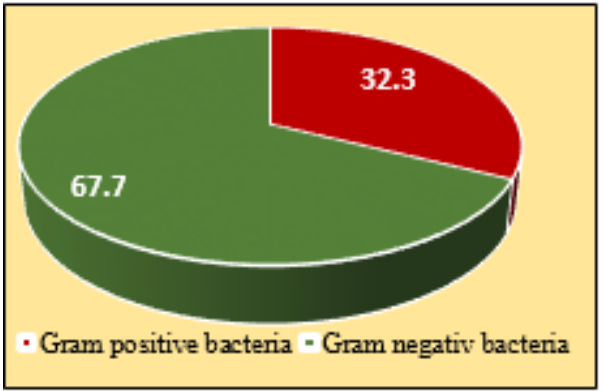

Fig.2. Microbiological profile of SSI pathogens

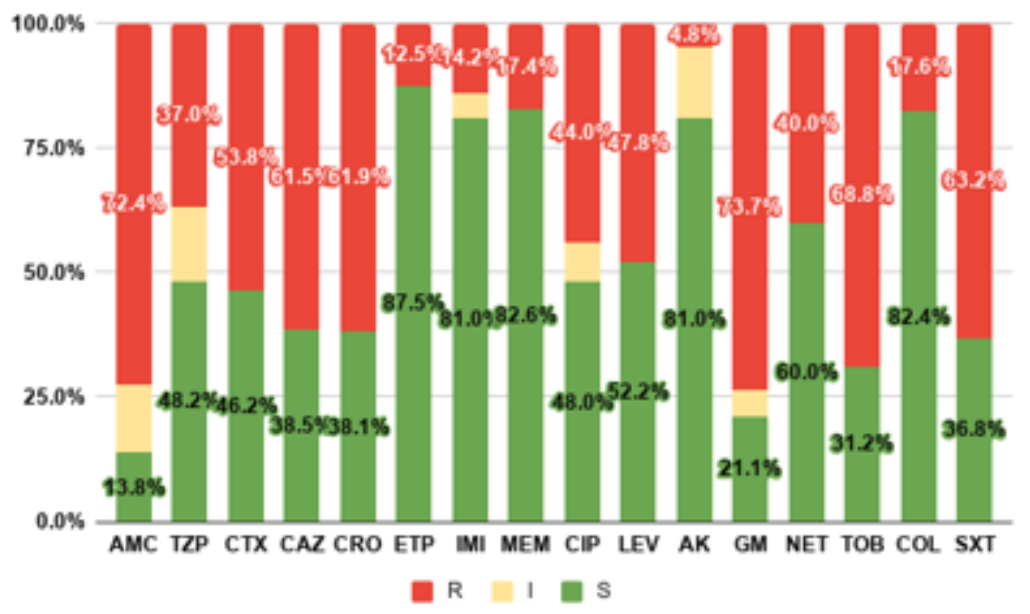

Fig.3 Klebsiella pneumoniae strains susceptibility to antibiotics 
The identified Staphylococcus aureus strains showed a highsusceptibility to Linezolid (LNZ) (100\%), Vancomycin (VAN) (100\%), and Teicoplanin (100\%) followed by Levofloxacin (LVX) (27.3\%), Rifampicin (RIF) (23.5\%) and Cefoxitin (FOX) (21.4\%). In contrast, a high resistance was observed with Ciprofloxacin (92.0\%), Cefoxitin (78.6\%) Erytromycin (86.2\%), Daptomicyn( $85.7 \%$ ) and Rifampicin (76.5\%). (table 2)

Antibiotic susceptibility testing revealed that strains isolated from Staphylococcus aureus were methicillinresistant in a proportion of $78.6 \%$, higher compared to the results reported by other authors: Abdoli, 2014 [38], Kadkhodaei, 2018 [36], Fehr et al. 2006 [34], Rosenthal et al. 2006 [35]Carter, 2005, [39]. In Europe the median percentage of methicillin resistance (MRSA) by population was $16.9 \%$ in 2017 with a significant downward trend between 2014 and 2017. In Romania the reported resistance wasof $10 \%-25 \%$. [17]

Acinetobacter baumanii isolated strains displayed a high susceptibility to Colistin (COL)(100\%), Netilmicin (NET) $(75.0 \%)$ and Tobramycin (TOB) $(69.2 \%)$ and were resistant to Meropenem (MEM) (87.0\%), Gentamicin (GEN) $(85.0 \%)$, Ciprofloxacin (CIP) $(84.0 \%)$ and Imipenem (IMI) $(83.3 \%)$ (table 3$)$. More than half of the isolated Acinetobacter spp. (55.0\%) reported by the European countries to EARS-Net for 2017 are resistant to at least one of the antimicrobial groups under regular surveillance, as fluoroquinolones, aminoglycosides and carbapenems. In Romania, the resistance to fluoroquinolones, aminoglycosides, carbapenems and the combined resistance to

\begin{tabular}{|l|l|c|c|c|}
\hline Staphylococcus aureus & & & & \\
\hline \multicolumn{1}{|c|}{ Antimicrobial group } & \multicolumn{1}{|c|}{ Antimicrobial agents } & S & I & R \\
\hline Cephalosporins & Cefoxitin FOX & $21.4 \%$ & $0.0 \%$ & $78.6 \%$ \\
\hline Fluoroquinolones & Ciprofloxacin CIP & $4.0 \%$ & $4.0 \%$ & $92.0 \%$ \\
\hline & Levofloxacin LEV & $27.3 \%$ & $0.0 \%$ & $72.7 \%$ \\
\hline Aminoglycosides & AmikacinAK & $30.0 \%$ & $20.0 \%$ & $50.0 \%$ \\
\hline & Gentamicin GM & $28.6 \%$ & $4.7 \%$ & $66.7 \%$ \\
\hline Glycopeptides & Teicoplanin TEC & $100.0 \%$ & $0.0 \%$ & $0.0 \%$ \\
\hline Macrolides & Vancomycin VAN & $100.0 \%$ & $0.0 \%$ & $0.0 \%$ \\
\hline Oxazolidinones & Erythromycin E & $6.9 \%$ & $6.9 \%$ & $86.2 \%$ \\
\hline Miscellaneous agents & Linezolid LNZ & $100.0 \%$ & $0.0 \%$ & $0.0 \%$ \\
\hline & Daptomycin & $14.3 \%$ & $0.0 \%$ & $85.7 \%$ \\
\hline & Rifampicin & $23.5 \%$ & $0.0 \%$ & $76.5 \%$ \\
\hline
\end{tabular}

Table 2

STAPHYLOCOCCUS AUREUS STRAINS SUSCEPTIBILITY TO ANTIBIOTICS

Table 3

ACINETOBACTER BAUMANII STRAINS SUSCEPTIBILITY TO ANTIBIOTICS

\begin{tabular}{|c|c|c|c|c|}
\hline \multicolumn{5}{|l|}{ Acinetobacter baumanii } \\
\hline Antimicrobial group & Antimicrobial agents & $\mathbf{S}$ & I & $\mathbf{R}$ \\
\hline \multirow[t]{2}{*}{ Penicillins } & Ampicillin-sulbactam SAM & $19.0 \%$ & $0.0 \%$ & $81.0 \%$ \\
\hline & Piperacillin-tazobactam TZP & $7.1 \%$ & $7.1 \%$ & $85.8 \%$ \\
\hline \multirow[t]{2}{*}{ Cephalosporins } & Ceftazidime CAZ & $14.3 \%$ & $0.0 \%$ & $85.7 \%$ \\
\hline & Ceftriaxone CRO & $9.5 \%$ & $4.8 \%$ & $85.7 \%$ \\
\hline \multirow[t]{2}{*}{ Carbapenems } & Imipenem IMI & $16.7 \%$ & $0.0 \%$ & $83.3 \%$ \\
\hline & Meropenem MEM & $8.7 \%$ & $4.3 \%$ & $87.0 \%$ \\
\hline \multirow[t]{2}{*}{ Fluoroquinolones } & Ciprofloxacin CIP & $16.0 \%$ & $0.0 \%$ & $84.0 \%$ \\
\hline & Levofloxacin LEV & $17.4 \%$ & $8.7 \%$ & $73.9 \%$ \\
\hline \multirow[t]{4}{*}{ Aminoglycosides } & Amikacin AK & $20.0 \%$ & $0.0 \%$ & $80.0 \%$ \\
\hline & Gentamicin GM & $15.0 \%$ & $0.0 \%$ & $85.0 \%$ \\
\hline & Netilmicin NET & $75.0 \%$ & $0.0 \%$ & $25.0 \%$ \\
\hline & Tobramycin TOB & $69.2 \%$ & $0.0 \%$ & $30.8 \%$ \\
\hline \multirow[t]{2}{*}{ Miscellaneous agents } & Colistin COL & $100.0 \%$ & $0.0 \%$ & $0.0 \%$ \\
\hline & Trimethoprim-sulfamethoxazole & $33.3 \%$ & $6.7 \%$ & $60.0 \%$ \\
\hline
\end{tabular}




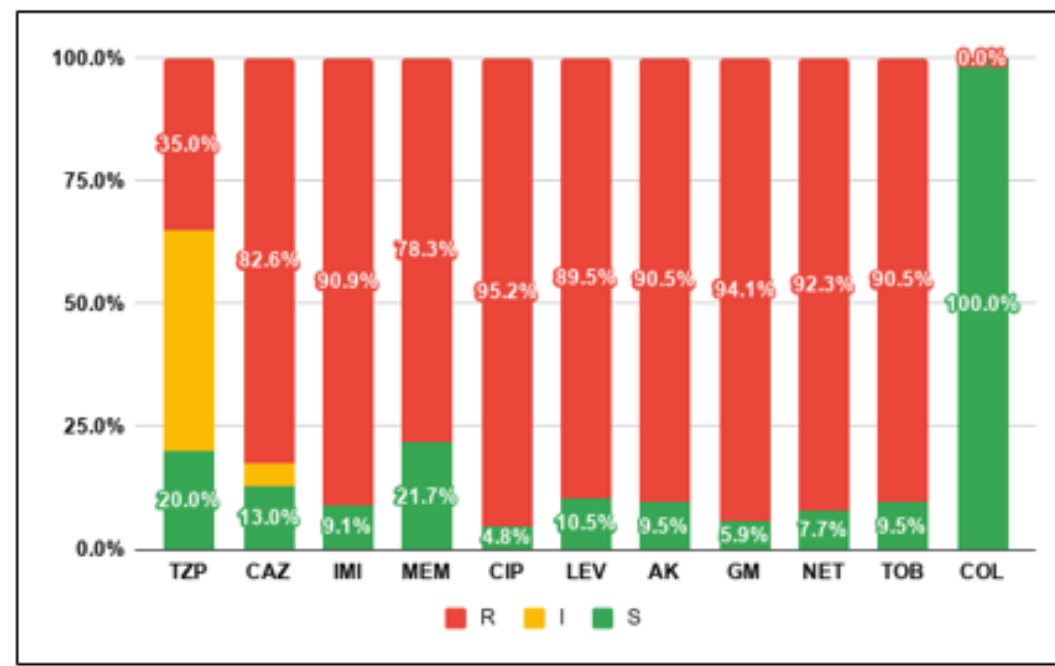

fluoroquinolones, aminoglycosides and carbapenems was over $50 \%[17]$.

Pseudomonasaeruginosa strains showed a highsusceptibility to Colistin (COL) (100\%) and an intermediate susceptibility to Piperacillin-tazobactam $(45.0 \%)$ and were resistant in proportion over $80 \%$ toCiprofloxacin(CIP) (95.2\%), Gentamicin (GM) (94.1\%), Imipenem (IMI) (90.9\%), Amikacin(AK) (90.5\%),, Netilmicin(NET) (92.3\%), Tobramycin (TOB) (90.5\%), Levofloxacin (LEV) (89.5\%), Ceftazidime (CAZ) (82.6\%)(fig.4). In European Union the highest average percentage of resistance in 2016 was reported for piperacillin \pm tazobactam (16.3\%), followed by fluoroquinolones $(15.0 \%)$, carbapenems $(15.0 \%)$, ceftazidime (13.0\%) and aminoglycosides [17].

The results of our study reveal a high level of resistance to antibiotics of the pathogens associated with SSI confirming the literature findingswhich demonstrates that up to $60 \%$ of microorganisms isolated from infected surgical wounds are resistant to antibiotic treatment [3].Resistance to antibiotics is a major problem in the hospital environment, with a gradual but marked change in bacterial epidemiology with significant implications for the prevention and cure of infections. In Europe it is demonstrated that $75 \%$ of the burden of bacteria resistant to antibiotics is due to healthcare-associated infections. The impact of antimicrobial resistance extends beyond the increased health risks and has many consequences and major implications for public health systems being associated with financial losses in the global economy due to reduced productivity and higher treatment costs. In order to limit them, there is a need for long-term financial investment and technical support, especially in developing countries,cautious use of antibiotics, the emergence of new antimicrobial drugs, new diagnostic techniques, vaccines and other interventions to ensure adequate the use and access to efficient antimicrobial agents [40].

\section{Conclusions}

The incidence of healthcare-associated infections is increasing as a major problem for healthcare systems around the world with medical, financial, social, and ethical implications. Surgical site infections occur with an increased frequency associated primarily with tumour pathology surgery.Most pathogens involved in the aetiology of SSI are resistant to antibiotics, a phenomenon that characterizes the evolution of bacterial epidemiology in the medical units.In order to prevent and control the SSI standardized strategies are recommended with proven effectiveness in a global, multidisciplinaryand innovative approach.

Fig.4. Pseudomonas aeruginosastrains susceptibility to antibiotics

\section{References}

1.HAQUE M, SARTELLI M, MCKIMM J, ABU BAKAR M. Infect Drug Resist. 11, 2018, p.321-2333.

2.REVELAS A. Niger Med J .53, nr.2, 2012, p.59-64.

3.**W HO The burden of health care-associated infection worldwide. 2016. http://www.who.int/gpsc/country_work/burden_hcai/en/.

4.MARÍA ISABEL MOROSINI AND RAFAEL CANTÓNREv. Esp. Quimioter.,31, Suppl 1, 2018, p.23-26.

5.WOELTJE K. F.,. LIN M.Y., KLOMPAS M., WRIGHT M. O. , ZUCCOTTI G.,. TRICK W. E. Infection Control and Hospital Epidemiol.35, nr.9, 2014, p.1083-1091.

6.0WENS CD, STOESSEL K. J. Hosp. Infect. 70 ,Suppl 2, 2008, p.3-10. 7.***Ordinul nr. 1101/2016 al MS privind aprobarea Normelor de supraveghere, prevenire si limitare a infeciilor asociate asistenei medicale in unitatile sanitare.https://lege5.ro/Gratuit/geztanjsgmzq/ ordinul-nr-1101-2016-privind-aprobarea-normelor-de-supraveghereprevenire-si-limitare-a-infectiilor-asociate-asistentei-medicale-inunitatile-sanitare

8.BENEDETTA ALLEGRANZI, SEPIDEH BAGHERI NEJ AD, CHRISTOPHE COMBESCURE, WILCO GRAAFMANS, HOMA ATTAR, LIAM DONALDSON, DIDIER PITTET.The Lancet, 377 , nr.9761, 2011, p.228241.

9.LEE DH, KIM SY, NAM SY, CHOI SH, CHOI JW, ROH J L. Oral Oncol..,47, 2011, p.528-31.

10.LOTFI CJ, CAVALCANTI RDE C, SILVA AM C E, LATORRE MDO R, ET AL.. Otolaryngol Head Neck Surg,. 138, nr.1.,2008, p.74-80.

11.CUNHA TF, SOARES MELANCIA TA, ZAGALO FERNANDES RIBEIRO CM, ET AL. J. Craniomaxillofac Surg.,40, 2012, p.443-448.

12.HIRAKAWA H, HASEGAWA Y, HANAI N, OZAWA T, HYODO I, SUZUKI M.. Eur Arch. Otorhinolaryngol.270, 2013, p.1115-1123.

13. HERNAIZ-LEONARDO JC, GOLZARRI MF, CORNEJ 0-JUÁREZ P, VOLKOW P, VELÁZQUEZ C, OSTROSKY-FRID M, VILAR-COMPTE D., 2017,45, nr. 1,p.761-766.

14.***Global action plan on antimicrobial resistance.United Nations high-level meeting on antimicrobial resistance www.who.int/ antimicrobial-resistance/events/UNGA-meeting-amr-sept2016/en/

15.***ECDC Characteristics of European acute care hospitals. Healthcare-associated infections, antimicrobial use and antimicrobial resistance. 2017. ecdc.europa.eu/en/publications-data/what-areeuropean-hospitals

16.NORINA FORNA, SAMI SANDHAUS, Romanian Journal of Oral Rehabilitation, 3, nr. 3, 2011, p.23-26.

$17{ }^{* * *}$ European Centre for Disease Prevention and Control. TESSy The European Surveillance System. Antimicrobial resistance (AMR) reporting protocol 2018. European Antimicrobial Resistance Surveillance Network (EARS-Net) surveillance data for 2017. ecdc.europa.eu/sites/portal/files/documents/EARSNet\%20reporting\% 20protocol\%202018.\%20docx.pdf www.ecdc.europa.eu/sites/portal/ files/documents/EARS-Net-report-2017-update-jan-2019.pdf 
18.TACCONELLI E, ET AL. Lancet Infect. Dis. 18, 2018, p.318-327. 19.VALIENTE E,.CAIRNS M D,.WREN BW. Clin. Microbiol. Infect.,20, 2014, p.396-404.

20.**ECDC Characteristics of European acute care hospitals. Healthcare-associated infections, antimicrobial use and antimicrobial resistance. 2017. ecdc.europa.eu/en/publications-data/what-areeuropean-hospitals

21.ONYEKWELU I, YAKKANTI R, PROTZER L, PINKSTON CM, TUCKER C, SELIGSON D. J. Am. Acad. Orthop.Surg. Glob. Res. Rev.,1, nr.32, 2017, :e022.

22.0GIHARA H, TAKEUCHI K, MAJ IMA Y. Auris Nasus Larynx., 36, 2009, p.457-460.

23.YANG CH, CHEW KY, SOLOMKIN JS, LIN PY, CHIANG YC, KUO YR.Ann Plast Surg., 71, Suppl 1, 2013, p.55-60.

24.ASSAEL, L. A. J ournal of Oral and Maxillofacial Surgery, 63, nr.7,2005, p.889-890.

25.PARK SY, KIM MS, EOM JS, LEE JS, RHO YS. Korean J. Intern. Med.,31, nr.1,2016,p.162-169.

26.BELUSIC-GOBIC M, CAR M, JURETIC M, CEROVIC R, GOBIC D, GOLUBOVIC V. Oral Oncol., nr. 43, 2007, p.77-81.

27.SCHWARTZ SR, YUEH B, MAYNARD C, DALEY J, HENDERSON W, KHURI SF. Otolaryngol Head Neck Surg., nr.131, 2004, p.61-68. 28.GRANDIS JR, SNYDERMAN CH, JOHNSON JT, YU VL, D'AMICO F., Cancer, nr. 70, 1992, p.2166-70.

29.DURAND ML, YARLAGADDA BB, RICH DL, LIN DT, EMERICK KS, ROCCO JW, DESCHLER DG. Laryngoscope.,125, nr.5, 2015,p. 1084-9. 30.YAO CM, ZIAI H, TSANG G, ET AL. J Otolaryngol Head Neck Surg. 46, nr.1, 2017, p.30
31.DE MELO GM, RIBEIRO KDCB, KOWALSKI LP, DEHEINZELIN D. Arch. Otolaryngol. Head Neck Surg., 127, nr.7, 2001, p.828-833. 32.DONKOR E. S. Trop. Med. Infect. Dis.,nr.4, 2019, p. 14.

33.PENEL N, LEFEBVRE D, FOURNIER C, SARINI J, KARA A, LEFEBVRE JL. Head Neck.nr. 23, 2001, p.447-455.

34.FEHR J, HATZC, SOKA I, KIBATALA P, URASSA H, SMITH T, MSHINDA H, FREI R, WIDMER A.. Infect Control Hosp Epidemiol. 14, nr.12, 2006, p.1401-1404.

35.ROSENTHAL VD, MAKI DG, SALOMAO R, MORENO CA, MEHTA Y, HIGUERA F, CUELLAR LE, ARIKAN OA, ABOUQAL R, LEBLEBICIOGLU H. Ann Intern Med.,14, nr.8, 2006, p.582-591.

36.KADKHODAEI M, SHARIF MR, SABA MA, MOUSAVI GA. Int Arch Health Sci,. nr.5, 2018, p.11-15

37.***The European Committee on Antimicrobial Susceptibility Testing. Breakpoint tables for interpretation of MICs and zone diameters. Version 9.0, 2019. http://www.eucast.org.)

38.ABDOLI OSKOUIE S, AHANGARZADE REZAIE M, PANAHI F, FIROOZI F, ES. HAGHI M, ET AL.Arch Pediatr Infect Dis, 2, nr.2, 2014, p.217-224 CARTER, T.G., DIERKS, E.J ., BRACIS, R. ET AL. J Oral Maxillofac Surg., 63, 2005, p. 1021.

39.SOLOMKIN J ., GASTMEIER P, BISCHOFF P., LATIF A., BERENHOLTZ S.,EGGER M. ET AL WHO Guidelines to prevent surgical site infection. 17, 2017, www. thelancet.com/journals/laninf/article/PIIS14733099(17)3008-6 .www.thelancet.com/infection

40.ALLEGRANZI B, BISCHOFF P, DE J ONGE S, KUBILAY NZ, ZAYED

$B$, GOMES SM, ABBAS M, ATEMA JJ, GANS S, VAN RIJEN

$M$, BOERMEESTER MA, EGGER M, KLUYTMANS J, PITTET

D, SOLOMKIN J S; Lancet Infect. Dis,. 16, nr.9, 2016 .p. 276-287

Manuscript received: 6.11 .2019 